\title{
Outro foco - a ironia no conto "quadrinho de estória"
}

\section{Gláucia Vieira Machado}

Resumo: Análise do conto de Guimarães Rosa, "Quadrinho de estória", em que podemos encontrar uma reflexão sobre as possibilidades e limitações da linguagem e uma proposta de transcendê-las pela infindável fonte de criação que é a memória. A partir de sua construção irônica, o texto poético de Guimarães Rosa mostra-se como produção inesgotável de sentidos, onde a linguagem é paradoxalmente recurso e obstáculo. 

O absurdo não está fora da razão. Todo projeto de racionalidade funda-se em algum paradoxo que, por sua vez, desdobra-se em inúmeras construções lógicas. O ocasional e o casual impõem-se no horizonte da possibilidade e exigem da linguagem o esforço de dizer o indizível, o imprevisível. Em Guimarães Rosa, o impossível é só uma questão de prefixo. A palavra se estende e a possibilidade de criar manifesta-se no narrar o comum, elevando-o ao sublime do irônico.

No conto "Quadrinho de Estória", ao flagrar um simples episódio, as imagens de um preso pelo vão de sua cela, suas e seus sonhos, Guimarães Rosa tece uma narrativa de apenas três paginas e meia onde aproxima vida e morte, liberdade e prisão. $\mathrm{O}$ autor reúne elementos aparentemente opostos de maneira estranha, isto é, confunde seus limites. Ao leitor fica uma sensação de falta de começo ou fim, pois as fronteiras da contradição rompem-se na ironia. ${ }^{1}$ Pela via da ironia, depara-se com a colocação perfeita das palavras no texto; Guimarães Rosa parece escolher palavras para compor um texto de pontuação marcada para cortes milimetricamente calculados. O resultado desse trabalho é uma narrativa ritmada, com velocidade própria, vizinha da poesia. Só que toda a perfeição conseguida no texto rosiano parece apontar a brecha, o lugar onde os encaixes bem talhados não dizem tudo.

"Quadrinho de Estória" é um texto que reflete sobre as múltiplas possibilidades da linguagem. A personagem do conto tem seu olhar limitado pela condição de prisioneiro, mas o perímetro de sua visão transcende o que ele vê pelo vão de sua cela. O narrador nos diz o que ele vê sem curiosidade, mas por necessidade. São seus olhos que respiram e recuperam, pelo visto, aquilo que ele transvê. Esse transvisto é lembrança.

Aquele que se lembra, no conto, é ironicamente prisioneiro, e está condenado à distância do lembrado, o que marca uma diferença entre eles. Ao mesmo tempo, aquilo que está longe parece mais perto do que nunca quando se torna lembrança encarnada numa imagem. A
${ }^{1} \mathrm{O}$ que mais nos chamou atenção no verbete "Ironia", do dicionário de Ferrater Mora, foi a ideia de "tensão entre elementos opostos". Essa observação nos levou a pensar nos "chistes" estudados por Freud, onde pudemos encontrar referências ao caráter antitético das palavras: a tensão insaturada já na formação das palavras na origem da linguagem. Também em Heidegger notamos uma preocupação semelhante no trato da noção de verdade, ALETHEA: o radical - lethea é esconder, velar, esquecer, deixar passar despercebido. $\mathrm{O}$ prefixo a-, de negação, compõe a palavra que se traduz, então, por "não esconder", "não velar". A indicação de que é possível chegarse ao contrário de um conceito pela sua negação recoloca a ideia de ironia: dizer mais do que se diz, dizendo o contrário. Isso nos remete, ainda, a uma afirmação de Lacan: "a verdade surge de equivocação." 
${ }^{2}$ ROSA, João

Guimarães. "Quadrinho de Estória” In: -.

Tutaméia - terceiras estórias. 5. ed. Rio de Janeiro, José Olympio, 1979 , p. 123. força do olhar está indicada nesse jogo de substituição: "Sempre outra vez tem de apoiar, nas tão vivas, que passam, a vontade de lembrança dela, e contemplo: o mundo visto e ação." 2 Esse parece ser o grande conflito do preso; incomoda-lhe tanto a transparência das pessoas quanto a transparência de sua lembrança. Numa tentativa de fundi-las, ele investe de ação sua lembrança ao impregná-la da visão, da imagem que dá contorno às suas recordações descontornadas.

Chegamos, assim, ao centro da discussão sobre a linguagem, dos clássicos aos nossos dias, em que observamos um confronto entre uma perspectiva idealista e outra nominalista. A questão parece ser: referir-se à linguagem enquanto universo de ideias, onde o que se busca é a essência, ou compreender-se a linguagem como realidade física, material, onde não existiriam entidades abstratas. Corre-se o risco, por esses caminhos, de ver-se na linguagem um mero "instrumento", ou, como Crátilo, discípulo de Heráclito, de abandonar as palavras e passar a apontar as coisas.

Para contrapor e aproximar as duas posições mencionadas, podem-se utilizar as referências feitas por Gilles Deleuze à significação e à designação. Aqueles que buscam a essência vão se pautar pela construção de significações, ao gosto platônico, o significado como sentido, o conceito como entidade real. Em resposta a uma significação pura, entretanto, temos a exemplificação, encarnação do conceito que perde seu caráter absoluto e reduz-se à particularidade. As designações acabam por mostrar a inviabilidade das significações puras; os corpos que sentem e falam cobram seu lugar nesse império do significado. Esse círculo vicioso de significação/designação é impossibilitador da linguagem: a cada nova significação surgiria um novo exemplo que devoraria o significado, perdendo, ao mesmo tempo toda possibilidade de traduzir-se em sentido. Seria possível em uma linguagem autodevoradora, onde, afinal, nem significados puros, nem designações sozinhas se sustentariam? Na definição de Homem dada por Platão e na (in)consequente 
exemplificação de Diógenes, encontramos o impasse dessa disputa: ao "o Homem é um bípede sem plumas", surge um galo desemplumado.

Das alturas das essências às profundezas dos exemplos, chega-se à impossibilidade da linguagem. Buscar um único sentido é inútil. Deleuze vai dizer que, por isso, é preciso resgatar a superfície, lugar do Acontecimento, onde o sentido não é mais único, mas desliza numa cadeia de significantes. "Estar no lugar de" significa e designa ao mesmo tempo; o sentido é, ironicamente, paradoxal, pois toma direções contrárias e simultâneas. Está implicada aí, inclusive, uma forma de pensar a história, o tempo.

Guimarães Rosa, em seu "Quadrinho de Estória", parece participar de toda essa reflexão filosófica. Ao prisioneiro não basta apenas a lembrança e tampouco a imagem de uma outra qualquer mulher. "A liberdade só pode ser um estado diferente, e acima." É o que diz a penúltima frase do conto; o diferente e acima é o que extrapola um sentido, é o lugar onde o descontorno e o contorno convivem ironicamente. E só a ironia pode justificar essa proximidade. O bom senso e o senso comum tentam apontar um sentido final, mas a linguagem não suporta tais limites. Parece ser isso o que nos mostra o conto rosiano, com seus sentido múltiplos, sempre aberto a uma outra leitura.

A estética da recepção já enfatizou o papel do leitor; esse novo sentido da leitura-produção do texto vem reforçar a noção do dialogismo, onde até mesmo a ideia de um sentido único, construído pelo Autor, perde a validade, já que o texto literário é no mínimo duplo: a escritura é simultaneamente subjetividade e comunicabilidade, ou seja, intertextualidade. Julia Kristeva, em seu estudo sobre Bakhtine, aponta o caráter dialógico e ambivalente do texto, ao enfatizar que a palavra escava sentidos horizontais (dialógicos: autor-leitor) e verticais (ambivalentes: texto na história, corpus literário). Essas vinculações no texto com elementos inerentes à linguagem (sua condição dialógica) e extralinguísticos (sua inserção na história) vêm reafirmar a impossibilidade 
${ }^{3}$ Idem, p. 122.

${ }^{4}$ Idem, p. 122.

${ }^{5}$ Barthes, em seu Prazer do Texto, refere-se ao texto como tecido. Ele salienta, porém, que durante muito tempo esse tecido foi visto como "produto", véu todo acabado por trás do qual existia, mais ou menos oculto, o sentido, a verdade. Um outro modo de ver esse tecido-texto é como processo de entrelaçamento em que o sujeito se desfaz, qual uma aranha se dissolve em sua teia. de se ler a não ser ironicamente. Isso porque, devido a esses fatores, nenhuma construção em linguagem é por si mesma e nenhum texto diz apenas o dito.

Parece interessar sobremaneira a Guimarães Rosa esse trabalho de linguagem que engendra novos sentidos. Se o ver é sempre apreender em falsificado alcance, o texto é onde a linguagem, ainda que aprisionada em sua "moldura", o código linguístico oficial, pode se soltar. No "Quadrinho de Estória", esse jogo ambíguo está encenado: estar aprisionado em uma página é, ao mesmo tempo, revelar-se.

Uma leitura desse conto, atentando-se para a questão da composição poética e sua ironia inerente, de início mostra o paralelo entre o prisioneiro e o poeta. A primeira constatação acerca do preso e a de que ele vê mais: "Mais vê-a o homem, mãos vazias e pássaros voando, cara colada às grades." ${ }^{3}$ Como o texto é todo construído por oposições irônicas, em seguida ao mais ver temos apontado o falsificado alcance: "Só em falsificado alcance ele a apreende." ${ }^{4} \mathrm{O}$ preso, assim como o poeta, vê mais, porém o alcance desse olhar é demarcado pela imaginação, solitário empreendimento de quem quer criar.

Esse ponto remete-nos a Schlegel e à sua definição de ironia enquanto impulso criador. Se, para aquele romântico poeta, esse criador era a divindade onipotente, para nosso poeta moderno o criador é um prisioneiro da página a ser escrita. Cheia de poder ou com seus poderes limitados, o que importa é que talvez a ironia seja a linguagem driblando suas limitações; ao ver-se enquanto tensão e reunião de opostos, a linguagem vê-se em metalinguagem, volta-se sobre si mesma a pensar-se, para criar. Afinal, ela é seu próprio recurso.

O gesto de escrever só pode ser de amor, única justificativa para a poesia, pois a vida que temos nos tem a todos em suas malhas e nos concede liberdade fatal, sem escapatória. Assim como a aranha tece sua teia movendose com avidez, o poeta compõe, tece imagens, figuras, reflexos e nexos no tetrágono. ${ }^{5}$ 
A página em branco o convida a construir, com a matéria de seu desengano, os contornos de sua lembrança. Quando Barthes diz "leio porque esqueço", podemos emendar, imaginando uma possível fala de Guimarães Rosa, "escrevo porque lembro". A memória é entidade fundamental na construção irônica; é ela que atualiza o acontecimento e permite-nos narrá-lo.

Nesse sentido, Quadrinho de Estória se apresenta como uma fotografia. A imagem conseguida é instantânea: "Desfaz o vazio, conforma o momentâneo, ocupa o arbitrário segmento, possível." $\mathrm{Com}$ esse flash, que evidencia a falta, temos a melhor parte: a lembrança. $\mathrm{O}$ que não está presente é, em verdade, transvisto no que está. Nesse jogo de ausência-lembrança, presentificado no acontecimento (a mulher do vestido azul no foco da praça), o texto se articula em significantes. Sua produção é um "efeito". Pode-se entender o que Lacan chama de significante ao se observar qualquer mulher no foco da praça, a partir da qual outra está sempre transvista. Assim, aquilo que representa o sujeito para outro significante produz o efeito de deixar-se transver.

No filme Possessão, de Andrej Zulawski, há uma frase que nos remete às considerações do prisioneiro do Quadrinho de Estória; a frase é: "Os assassinos ficam sempre com a melhor parte." Parece que essa "melhor parte" é a lembrança. Livre dos contornos habituais, ela alcança ironicamente uma posição mais elevada, pois é contornada pela imaginação. Aí temos seu ponto de superioridade: a lembrança é concretude criativa, está livre das malhas das intransparências da realidade. Isso talvez nos ajude a entender a curiosa afirmação que lemos no conto de Guimarães Rosa: "Viver seja talvez somente guardar o lugar de outrem, ainda diferente, ausente." $\mathrm{O}$ "estar no lugar de" pode ser entendido como o eterno lembrar-se e esquecer-se, a que estamos todos condenados. As lembranças nos constituem de uma maneira dinâmica; e, por isso, nuca se É, mas sempre se PARECE SER - esse o absurdo maior da condição humana. ${ }^{8}$ Aquela mulher que assusta o prisioneiro do conto por sua intransparência
${ }^{6}$ Op. cit., p. 123.

${ }^{7}$ Idem, p. 123.

${ }^{8}$ SER E PARAESSER. Lacan sugere a conjugação do verbo para-esser. Seu argumento é o de que não há Ser que seja por si mesmo, senão como significante. A possibilidade Ser é sempre em relação a Outro, o Ser só é na lateral. 
${ }^{9}$ Op. cit., p. 125

equívoca é um significante que representa um sujeito (a outra mulher, que já não existe mais e que nem sabemos se de fato existiu) para outro significante, que é o preso.

Nesse jogo de significantes, a estrutura do conto é descentrada exatamente porque não traduz uma busca de significado. O texto produz-se enquanto contingência, descontinuidade. A pontuação do conto é fraturada, entrecortada por sinais; Guimarães Rosa abusa das notações gráficas, principalmente das vírgulas e dos travessões. Esse recurso já nos leva a um estado de tensão diante da leitura. O leitor que, desavisado, cai na armadilha do conto, vê-se, ao final, em um labirinto. Afinal, qual é a estória? Há um preso que vê por trás das grades, pela fenda, pelo vão de sua cela; estamos no universo da "estória em quadrinhos", ironicamente ao avesso: não há desenhos com palavras inscritas, mas há palavras e frases e sinais que evocam imagens e compõem uma foto, um quadro. Esse quadro traz em si mesmo uma limitação, o humano limite que é uma linguagem.

Quando a estória termina com a frase: "A noite, o tempo, o mundo, rodam com precisão legítima de aparelho"', temos a ilusão de um fechamento grandiloquente. Ficamos em dúvida se o narrador está nos dizendo que há uma força centralizadora, doadora de um sentido final, ou se estamos diante de mais uma jogada irônica. Para um maior esclarecimento, podemos aproximar a "precisão legítima de aparelho" à ironia dos "olhos hodiernos" do preso, onde ocorrem "maquinais lágrimas". Essas expressões do conto vêm associadas à ideia de "rodar", último verbo que lemos no Quadrinho de Estória. Isso poderia levar-nos a uma compreensão circular da narrativa e, como consequência, a uma leitura centrada e monológica. A circularidade da narrativa, entretanto, encarada numa perspectiva irônica, pode extrapolar os limites de um discurso monológico, fechado em si mesmo.

Sobre a questão do centramento e da circularidade há uma interessante afirmação de Lacan em um de seus Seminários. Ele refere-se à revolução copernicana, tão 
aplaudida por Freud; da discussão acerca do centro, a partir do qual o universo giraria, Lacan mostra a insuficiência da noção de centro, e recusa aos postulados de Copérnico o qualitativo de revolucionário, pois seu efeito foi apenas alterar a posição do centro, sem questionar o centramento. Nas assertivas lacanianas, dizer que a terra gira só importa, de fato, enquanto efeito - por exemplo, o de se contar em anos uma pessoa. Foi quando Kepler formulou a equação $\mathrm{F}=\mathrm{gmm}$ ' que a revolução se instaurou: ele substituiu "ISSO GIRA" por "ISSO CAI". Ou seja, "isso gira em elipse, e já põe em questão a função do centro. O ponto para onde o "ISSO CAI", em Kepler, é um ponto de elipse, que se chama foco, e no ponto simétrico não há nada."10 A percepção circular do tempo ou de uma narrativa pode se dar de inúmeras maneiras, mas a que nos interessa é essa visão elíptica, correspondente ao anel de Mohebius, onde um lado se encontra com seu avesso e os cortes multiplicam as dobras infinitamente, sem contudo separá-las.

Com Guimarães Rosa, no final de seu conto, voltamos ao impasse de um mundo totalizado pelo efeito do tempo. Esta é mais uma observação irônica, entretanto, e nos remete à contraposição entre um lugar encerrado por aquele que fala e seu discurso que nunca se esgota em um sentido único. Isso ocorre porque tanto o "foco" da praça, no início do conto, onde está a mulher de vestido azul, como o "foco" de Kepler, onde o "ISSO CAI", não possuem correspondência simétrica com nada. O que está no foco cai, dando lugar a outro sempre diferente. Assim não há representação que esgote o referido, pois enquanto "mediação", a linguagem é paradoxalmente recurso e obstáculo. Por isso o carcereiro do conto, apesar de ter a chave, está dentro do cárcere. Por isso, o moço muito prisioneiro é um "pseudopreso", liberto pelo tempo de lembrança e esquecimento. Não há liberdade nem prisão para aquele que está numa esfera do tempo antagônica a Cronos; ao pseudopreso o tempo é Aion, passado e futuro subdividindo o presente infinitamente e nos dois sentidos simultaneamente.
${ }^{10}$ LACAN, Jacques.

O seminário - livro 20. Mais, ainda. Texto estabelecido por Jacques-Alain Miller. 2. ed. Rio de Janeiro: Jorge Zahar, 1985, p. 54. 


\section{Referências}

BARTHES, Roland. O prazer do texto. Trad. J. Guinsburg. São Paulo, Perspectiva (coleção Elos), 1997.

DELEUZE, Gilles. Lógica do Sentido. Trad. Luiz Roberto Salinas Fortes. São Paulo, Perspectiva, 1974.

FERRAZ, Maria de Lourdes A. A ironia rnmântica - estudo de um processo comunicativo. Lisboa, Imprensa Nacional - Casa da Moeda, s/d (1987).

FREUD, Sigmund. A significação antiética das palavras primitivas. In: - Obras psicológicas completas de Sigmund Freud. Indicado (vol. XI), trad. Jayme Salomão, Rio de Janeiro, Imago. 1970, p. 137-146.

KRISTEVA, Júlia. Introdução à semanálise. Trad. Lúcia Helena França Ferraz. São Paulo, Perspectiva, 1947.

LACAN, Jacques. O seminário - livro 20. Mais, ainda. Texto estabelecido por Jacques-Alain Miller. Trad. M. D. Magno. 2. ed. Rio de Janeiro: Jorge Zahar, 1985.

MORA, José Ferrater. Diccionario de Filosofía. Madrid, Allianza Editorial S.A., 1980.

ROSA, João Guimarães. Tutaméia (terceiras estória). 5. ed. Rio de Janeiro, José Olympio, 1979. 